\title{
Mothers-Offspring Resemblance in Intelligence and Its Relationship to Socioeconomic Status
}

\author{
Carmen Elvira Flores-Mendoza \\ Universidade Federal de Minas Gerais, \\ Belo Horizonte-MG, Brazil \\ Walkiria Peliky Fontes \\ Universidade Federal de Minas Gerais, \\ Belo Horizonte-MG, Brazil
}

\author{
Bruna Miranda Carvalhais Santiago \\ Universidade Federal de Minas Gerais, \\ Belo Horizonte-MG, Brazil \\ Larissa Assunção Rodrigues \\ Universidade Federal de Minas Gerais, \\ Belo Horizonte-MG, Brazil
}

\author{
Daniel Marcos Andrade \\ Universidade Federal de Minas Gerais, \\ Belo Horizonte-MG, Brazil \\ César Augusto Mansur Tuma \\ Universidade Federal de Minas Gerais, \\ Belo Horizonte-MG, Brazil
}

\begin{abstract}
Kinship studies have shown that most cognitive ability variances are attributable to genotypic variance. Additionally, kinship correlations are generally increased when tasks that are highly g loaded are considered, a result known as the "Jensen effect". Alternatively, some studies have suggested socioeconomic status as an important factor for explaining differences in cognition. The present study investigated these premises in a sample of 141 mothers (mean age $=36.6 ; S D=6.0)$ and their offspring $(53.2 \%$ girls; mean age $=$ 11.0; $S D=2.1$ ). The Standard Progressive Matrices of Raven (mothers and offspring) and six other cognitive measures (offspring only) were administered. The findings suggested evidence of $\mathrm{g}$ heritability (Jensen effect), which is consistent with published literature on intelligence. However, kinship correlation coefficients were lower (.041 to .177) when compared to other published findings. Finally, the difference between the mother's IQ score and that of her child was influenced by SES and mother's education level.
\end{abstract}

Keywords: genetic, intelligence, family study, socioeconomic status, educational status

\section{Semelhança Entre Mães e Filhos em Inteligência e sua Relação com o Nível Socioeconômico}

Resumo: Estudos familiares demonstram que grande parte da variância das habilidades cognitivas é atribuída à variância genotípica. Além disso, correlações de parentesco possuem, geralmente, maiores valores quando as tarefas são altamente carregadas de g, fenômeno conhecido como "efeito Jensen". No entanto, em outra linha de investigação, estudos sugerem que o nível socioeconômico é um fator importante para explicar as diferenças cognitivas. O presente estudo investigou essas premissas em uma amostra de 141 mães (idade media $=36,6 ; D P=6,0)$ e seus filhos $(53,2 \%$ meninas;idade média $=11,0 ; D P=2,1)$. Administrou-se as Matrizes Progressivas de Raven (em mães e filhos) e seis outras medidas cognitivas (nos filhos). Os resultados sugeriram uma evidência de herdabilidade em $g$ (efeito Jensen). No entanto, os coeficientes de correlações familiares foram menores $(0,041$ a 0,177$)$ a outros comumemente publicados. Por outro lado, a diferença entre os scores de QI das mães e de seus filhos foi influenciada pelo nível socioeconômico (NSE) e pelo nível de escolaridade da mãe. No geral, advoga-se por uma interação gene x ambiente das diferenças de habilidades cognitivas dependente do contexto socio-econômico.

Palavras-chave: genética, inteligência, estudo de família, nível socioeconômico, escolaridade

\section{Semejanza Entre Madres e Hijos e su Relacion con el Nivel Socioeconómico}

\begin{abstract}
Resumen: Los estudios familiares han mostrado que gran parte de la varianza de las habilidades cognitivas es dada por la varianza genotípica. Además, las correlaciones de parentesco generalmente tienen mayor valor cuando las tareas demandan alto g, fenómeno conocido como "efecto Jensen". Sin embargo, considerando otra línea de investigación, los estudios sugieren que el nivel socioeconómico es un factor importante para explicar las diferencias cognitivas. El presente estudio investigó estas premisas en una muestra de 141 madres (edad media $=36,6 ; D T=6,0)$ y sus hijos $(53,2 \%$ niñas; edad media $=11,0 ; D T=2,1)$. Fue administrado las Matrices Progresivas de Raven (en madres y niños) y otras seis medidas cognitivas (en niños). Los resultados sugieren evidencia de herdabilidad en $g$ (efecto Jensen), hallazgo consistente con la literatura. Con todo, los coeficientes de correlación de parentesco fueron inferiores (0.041 a 0.177$)$ en comparación con otras publicaciones. Finalmente, la diferencia entre las puntuaciones de CI de madres y sus hijos fue influenciado por el nivel socioeconómico (SES) y el nivel educativo de la madre.
\end{abstract}

Palabras clave: genética, inteligencia, estudio de familia, nivel socioeconómico, escolaridad

\footnotetext{
${ }^{1}$ Correspondence Address Autor: Av. Antonio Carlos, 6627. Faculdade de Filosofia e Ciências Humanas. Laboratorio de Avaliação das Diferenças Individuais. Universidade Federal de MinasGerais. Gab. 4042. Belo HorizonteMG. CEP: 31270-901 Email: carmenflor@uol.com.br / carmencita@ufmg.br 
Intelligence is defined by the ability to plan, reason, comprehend, perform abstract thinking, and learn (Gottfredson, 1997). Because of its positive association with success in education, profession, income and welfare (Deary, 2012), intelligence is considered the most important trait in psychology (Hunt, 2010). Heritability $\left(h^{2}\right)$, in turn, has been considered one of the longest standing assumptions about the nature of human intelligence (Bouchard \& McGue, 1981; Brouwer et al., 2014; Erlenmeyer-Kimling \& Jarvik, 1963; Halsey, 1958; Hanscombe et al., 2012; Harden, Turkheimer, \& Loehlin, 2007; Johnson \& Bouchard, 2007; Plomin \& DeFries, 1980; Scarr-Salapatek, 1971).

Considerable empirical evidence exists regarding the heritability of intelligence. Several studies have suggested that heritable intelligence can vary between 0.2 and 0.86 . In other words, 20 to $86 \%$ of the phenotypic variance observed in measured cognitive abilities is attributed to genetic factors (Bouchard \& McGue, 1981; Brouwer et al., 2014; Deary, Johnson, \& Houlihan, 2009; Erlenmeyer-Kimling \& Jarvik, 1963; Lynn \& Hattori, 1990; Nisbett et al., 2012; Plomin \& DeFries, 1980; Turkheimer, Haley, Waldron, D’Onofrio, $\&$ Gottesman, 2003). For instance, in a fundamental review that compared 111 studies worldwide, investigating familial IQ correlations (Bouchard \& McGue, 1981), the authors suggested an association of .86 for monozygotic (MZ) twins raised together and .72 for monozygotic twins raised separately. Decades later, similar observations were also reported (Lynn \& Hattori, 1990; Turkheimer et al., 2003). As expected, investigation of dizygotic twins demonstrated a positive, however lower correlation compared to MZ's results. For same-sex dizygotic pairs, correlation values were estimated to be between .43 and .62 (Bouchard \& McGue, 1981; Lynn \& Hattori, 1990).

Additionally, parent-offspring correlations have been reported at approximately .50 (Bouchard \& McGue, 1981; Caruso, 1983; Erlenmeyer-Kimling \& Jarvik, 1963; McCall, 1970; Plomin \& DeFries, 1980). While Bouchard and McGue (1981) found a correlation of .41 between father or mother and their offspring, a review consisting of 52 familial IQ correlation studies (Erlenmeyer-Kimling \& Jarvik, 1963) indicated a median correlation of .50 for parent-child raised together. Similarly, Caruso (1983) demonstrated an $\mathrm{N}$-weighted mean correlation of 0.51 after re-analyzing data from 15 samples, referred to parent-offspring pairs.

McCall (1970) also analyzed the cognitive performance correlation between parents and their children, of which both samples were evaluated at the same age, from 3 until 12 years of age. The highest correlation was .50 , at age 4 and the lowest was .17 at age 11 . In general, most of the analyzed pairs demonstrated a low correlation, with a median of 29 . The author suggested that the many years separating the parent-child assessment, which was taken at the same age, was what resulted in the low correlations.

Cousins are less biologically related individuals and, as expected, their results in cognitive tests display lower correlations. Bouchard and McGue (1981) have indicated a correlation coefficient of .15. When considering unrelated individuals raised together (e.g. adopted children), the correlation was .23 and close to 0 for unrelated people that were reared apart (such as children living in the same orphanage or foster home from an early age) (ErlenmeyerKimling \& Jarvik, 1963).

These results are in agreement with polygenic inheritance, which predicts that a pair of individuals who have a stronger genetic similarity will also have similarly higher IQs correlations (Bouchard \& McGue, 1981). No statistically significant effect of sex from parents or their children on parents-offspring resemblance in intelligence was observed (McAskie \& Clarke, 1976; Reed \& Rich, 1982).

On the other hand, there is evidence that kinship correlations differ according to the variation of the tests' $g$ loadings (Colom, Juan-Espinosa, \& Garcia, 2001; Jensen, 1998). For instance, it has been suggested that when a more complex cognitive test is applied, the more the contribution of $g$ is observed. Therefore, what is $g$ ? In this situation, $g$ is the general intelligence that influences all mental abilities. In statistical terms, $g$ is the principal factor accounted for by the variance within diverse mental tests. It is the "working definition of intelligence", as Gottfredson (1997) asserts. And according to Jensen, $g$ is the most heritable cognitive factor (Jensen, 1998). Thus, stronger kinship correlations are expected when tasks that are highly $g$ loaded are considered. Additionally, evidence of $g$ loading on the magnitude of human heritability tests (Luo, Petrill, \& Thompson, 1994), and non-human heritability tests (Woodley, Fernandes, \& Hopkins, 2015) have previously been reported. Thus, $g$ loading is the first indicator that must be considered in studies regarding parents-offspring resemblance in intelligence.

Beyond $g$, current psychometric literature (Carroll, 1993; McGrew, Flanagan, Keith, \& Vanderwood, 1997) recognizes the importance of two broad cognitive abilities, Fluid Intelligence $(G f)$ and Crystallized Intelligence $(G c)$, originally identified by Raymond Cattell and further developed by his student, Horn (1994). While $G f$ is the ability to reason, form concepts and problem solve using novel information, $G c$ is the ability to use general and cultural knowledge, including verbal communication with previously learned procedures. It can be noted that $G f$ instead $G c$ could be less sensitive to environmental intervention, and, in principle, $G f$ may impact the resemblance between parents-offspring in intelligence. However, until now the only study linking heritability across cognitive abilities was the study of Kan, Wicherts, Dolan and van der Maas (2013). Contrary to traditional assumptions, this study identified that most heritable abilities are in fact the most culture-dependent abilities, i.e., $G c$ would be more heritable than $G f$. This is an indicator that must be further investigated in cross-cultural research, especially in developing countries.

On the other hand, the majority of behavioral genetic studies in human, of which the majority were conducted in developed countries, did not take into account the influence of environmental aspects, such as parental income, parental education and parental occupation, factors that, together, refers to familial socioeconomic status (SES). For these reasons, Turkheimer et al. (2003) evaluated the influence of low-SES on mothers and twin children cognition. For the high-SES group, heritability was estimated at .72, as 
previously showed by Bouchard and McGue (1981), but for the low-SES group, surprisingly, the $h^{2}$ decreased to .10 . Similar results were reported by Rowe, Jacobson and Van den Oord (1999) regarding the moderating effect that parental attained educational level has on the vocabulary level in 16year old children.

On the contrary, Nagoshi and Johnson (2005), when controlling for the effect of socioeconomic status (SES) on parent-child cognitive interaction, did not confirm that lowSES acts to minimize the influence of heredity on intelligence.

Harden et al. (2007) reanalysis of Turkheimer et al. (2003) study from 839 twin pairs found the same pattern reported by Turkheimer et al. However non-significant differences in heritability were observed between the SES ( $40 \%$ of variance accounted for additive genetics for families from the lowest incomes and 55\% for families from the highest incomes.) Perhaps this result was due to the fact that most of the samples were not actually considered low SES.

Recently, a meta-analysis was published by TuckerDrob and Bates (2016) with the aim of understanding the paradox: gene $x$ SES interaction effects on individual differences in intelligence and school performance. Fourteen independent studies comprising a total of 24,926 pairs of twins and siblings were analyzed. The results indicated a significant gene $x$ SES effect $\left(\mathrm{a}^{\prime}=.074, \mathrm{SE}=.020, p<.0005\right)$ for studies conducted in USA; but no significant gene x SES effect $\left(a^{\prime}\right.$ $=-.027, \mathrm{SE}=.022, p=.223$ ) was observed in non-USA studies (Western Europe and Australia). No other mediators, such as type of cognitive or school performance test, single or composite measure of SES, were statistically significant. That author's hypothesis aimed to explain that those results were related to the access to high-quality education and health care, which is more uniform in Western Europe and Australia than in USA. Tucker-Drob and Bates asserted that effects of family SES on cognitive development must be carefully considered in genetic studies.

On the other hand, a better understanding of gene $x$ SES interaction allows for possible explanations for the cognitive gains across generations (also known as Flynn effect). To date, there is no conclusive answer as to why the current generation (e.g. offspring) displays higher scores in intelligence test than past generations (e.g. parents) (Pietschnig \& Voracek, 2015). These gains were estimated around 3 points of IQ per decade (Flynn, 1994), or 7.5 points of IQ in a generation (25 years). This rapid increase cannot be due to genetic factors. There would be a " $\mathrm{X}$ " factor, which permits the increase of intelligence (Flynn, 1999). In fact, Dickens and Flynn (2001) proposed the "hypothesis of social multipliers" according to which even slight environmental advantages (e.g. good social policies) could lead to improve individual performance in cognitive and school measures, and this improved performance will lead to a better environment, and so on. Other studies has denied this hypothesis (Rowe \& Rodgers, 2002). However, this is an indicator that should be investigated further in order to understand the cognitive gains, as seen from the results of
Tucker-Drob and Bates (2016) and Turkheimer et al. (2003). If these results are robust, we can expect that correlations between parents-offspring (irrespective of treatment of intelligence as $g$ or $G f / G c$ ) must tend to be statistically nonsignificant in samples with low SES, favoring the operation of "X" factor. Cognitive differences between parents and offspring, favoring offspring, should therefore be higher in families with low SES.

Brazil is a country with high levels of social iniquity (http://data.worldbank.org/indicator/SI.POV.GINI), where gene $x$ SES interaction effects can be better tracked. For instance, a Brazilian study has indicated that, as expected, SES affects more $G c$ than $G f$ (Flores-Mendoza, Widaman, Mansur-Alves, Bacelar, \& Saldanha, 2013). However, to date, there is no information regarding how SES could affect the heritability of intelligence using a parent-offspring design. Thus the aims of this study was to verify: 1) kinship correlations (mother-offspring) and the effect Jensen ( $g$ loading) in these correlations, 2) correlations of heritability across cognitive abilities, such as $G f$ and $G c, 3$ ) the impact of SES on kinship correlations (mother-offspring), and 4) cognitive differences between mother and their offspring in the same cognitive measure, taking into account SES and education level of mothers.

To the extent of our knowledge, it is the first study in Brazil presenting information about resemblance in intelligence from parents and offspring.

\section{Method}

\section{Participants}

The present study was part of a larger project entitled, "Psychological Assessment of cognitive and school performance of children from an urban and rural context". The study was conducted in 2006 in the city of Perdões, in the state of Minas Gerais, Brazil. Perdões is 211 kilometers from Belo Horizonte (the capital city of Minas Gerais) with 270,657 $\mathrm{km}^{2}$ of total area and approximately 20,000 inhabitants (2010 census).

There were 374 students (196 girls and 178 boys) that participated in this project, of which $15.5 \%$ were enrolled in seven rural schools (which represents all rural schools that exist in the city) and $84.5 \%$ were enrolled in three urban schools. All parents were invited to participate of the study, however only 156 parents (15 fathers and 141 mothers) were available for the parental assessment. Parents that were unable to attend the psychological assessment (around 60\% of the initial sample) cited work conflicts. Thus, in the present study, data was reported from 141 paired (mothers and children) participants, $16.5 \%$ of pairs related to students enrolled in three rural schools and $83.5 \%$ enrolled in three urban schools. According to the social questionnaire filled out by parents, all mothers were biological mothers of their kids and there was no twins or siblings among students. Descriptive data are shown in Table 1. 
Table 1

Sample description of mothers and offspring

\begin{tabular}{|c|c|c|c|}
\hline Participants & & bles & $\%$ \\
\hline \multirow{11}{*}{ Mothers } & \multirow{3}{*}{ Age } & $25-30$ & 20.6 \\
\hline & & $31-40$ & 56.7 \\
\hline & & $41-53$ & 22.7 \\
\hline & \multirow{3}{*}{ Education } & Primary school & 53.8 \\
\hline & & High school & 37.1 \\
\hline & & University & 9.1 \\
\hline & \multirow{5}{*}{ SES } & B1 & 0.8 \\
\hline & & B2 & 9.1 \\
\hline & & $\mathrm{C} 1$ & 25.6 \\
\hline & & $\mathrm{C} 2$ & 38.8 \\
\hline & & $\mathrm{D}$ & 25.6 \\
\hline \multirow{11}{*}{ Offspring } & \multirow{2}{*}{ Sex } & Girls & 53.2 \\
\hline & & Boys & 46.8 \\
\hline & \multirow{5}{*}{ Age } & $7-8$ & 12.8 \\
\hline & & $9-10$ & 29.0 \\
\hline & & $11-12$ & 28.4 \\
\hline & & $13-14$ & 22.0 \\
\hline & & 15 & 7.8 \\
\hline & \multirow{4}{*}{ School grade } & $1 \mathrm{frst}-2 \mathrm{sd}$ & 25.5 \\
\hline & & 3 th $-4^{\text {th }}$ & 41.8 \\
\hline & & $5^{\text {th }}-6^{\text {th }}$ & 14.2 \\
\hline & & $7^{\text {th }}-8^{\text {th }}$ & 18.5 \\
\hline \multirow{2}{*}{ Students } & \multicolumn{2}{|l|}{ Urban schools } & 84.5 \\
\hline & \multicolumn{2}{|l|}{ Rural schools } & 15.5 \\
\hline
\end{tabular}

\section{Instruments}

Intelligence was measured by the Standard Progressive Matrices - (SPM). (Raven, 2001). SPM is considered to be a measure of fluid intelligence, or G $f$ (Jensen, 1998). The internal consistency (alpha Cronbach) of SPM for mothers was .934 and for their offspring, .936. Furthermore, the offspring sample was also assessed by using five subtests of the Wechsler Intelligence Scale for Children-III subtest (Wechsler, 2002). Two subtests considered as crystallized intelligence measurements, or Gc (Jensen, 1998), included: information and similarities (alpha Cronbach of .80 and .76, respectively). Three subtests considered as fluid intelligence measures included: Blocks, Symbol Search and Code subtest (reliability re-test, $r=.80, .63$, and .70 respectively). Additionally, the Toulouse test (Rainho, 2001) for measuring attention reliability by re-test of .66 according study of Araujo (2011) was also applied to offspring.

Family SES was estimated using Criterio Brasil (Associação Brasileira de Empresas de Pesquisa [ABEP], 2008) which is based on two sources: availability and quantity of resources within the home (e.g. TV, washing machine, refrigerator, etc.), and parents' education level. The points accumulated by each item are calculated and converted into a classification scale (e.g., $1 \mathrm{TV}=1$ point, whereas $3 \mathrm{TVs}$ $=3$ points; 1 bathroom $=4$ points, whereas 2 bathroom $=5$ points). Levels of SES ranged from A1 (highest SES level) to E (lowest SES level). This information was available to 121 mothers (or $86 \%$ of total sample) and its distribution was: $0.8 \%$ for $\mathrm{B} 1 ; 9.1 \%$ for $\mathrm{B} 2 ; 25.6 \%$ for $\mathrm{C} 1$ level; $38.8 \%$ for $\mathrm{C} 2$ and $25.6 \%$ for D level. Thus, the sample of the present study was predominantly concentrated (64\%) between low (D) and low-middle class (C1) SES. Additionally, the social questionnaire included items regarding level of kinship between parents and children (biological, relative or adopted), and other information not analyzed for the present study (e.g. race, level of religiosity, and political orientation of parents).

\section{Procedure}

Data collection. The Secretary of Education from Perdões County previously invited public school principals from rural and urban zones to participate in this study. The school's principals, in turn, invited the parents to participate. Informed written consent was obtained from all participants. A team of psychology students and two professors (authors of the present study) remained in the city for a week, thanks to the support of the county's Education Secretary, in order to perform the evaluations. The SPM test was administered collectively in school classrooms for children enrolled in the 3rd grade or above. The subtests of WISC III (Information, Similarities, Block, Symbols Search and Code), and the SPM test (only for children attending the $1^{\text {st }}$ and $2^{\text {nd }}$ grade), were administered individually in a special room provided by the school. Parents were collectively assessed in the last day, in two school classrooms.

Data analysis. Careful effort was given to control a developmental effect on cognitive measures (for offspring correlations between SPM, information, similarities, blocks, symbol search, code Toulouse with age, revealed values of $.595, .639, .590, .520, .604, .633$, and .582 , respectively; while for mothers, the correlation between SPM and age was -.221). All raw scores were normalized to a $z$ score, controlling for age. Additionally, an exploratory factorial analysis through principal axis factoring was conducted, which considers only common variance when extracting the factorial load of each cognitive measure based on the principal factor $(g)$. The correlation values were disattenuated for reliability of the measurements, using the following formula:. $r 12=\frac{r 12}{\sqrt{r 11 r 22}}$

In this equation, $r_{12}$ is the observed correlation, and $r_{11}$ and $r_{22}$ are the reliability estimates of measures 1 and measures 2 . The normalization of the raw SPM score (from mothers and offspring) was converted to an IQ scale [( $\left.\left.\mathrm{z}^{*} 15\right)+100\right]$. Finally, a linear model (Montgomery, Peck, \& Vining, 2006) that contrasted the groups was estimated to verify the interaction between SES and education level of mothers with regards to IQ differences. Analysis was performed using software R, version 3.2.0 (Venables, Smith, \& R Core Team, 2015). 


\section{Ethical Considerations}

Ethical approval (Process n. 089/06) was obtained by the ethical committee at the Universidade Federal de Minas Gerais.

\section{Results}

Table 2 indicates the load of each cognitive measure on the principal factor $(g)$ and the cognitive performance correlation between mothers (SPM test) and their offspring.

Table 2

Correlation between cognitive performance of offspring and mothers

\begin{tabular}{lcc}
\hline \multicolumn{1}{c}{$\begin{array}{c}\text { Cognitive measures } \\
\text { (offspring) }\end{array}$} & Load $g$ & $\begin{array}{c}r \text { with SPM of } \\
\text { mothers }\end{array}$ \\
\hline SPM & .844 & $.143(.153)$ \\
Similarities & .823 & $.177(.201)^{*}$ \\
Information & .794 & $.166(.192)^{*}$ \\
Block Design & .764 & $.152(.174)$ \\
Code & .728 & $.087(.108)$ \\
Toulouse & .721 & $.101(.129)$ \\
Symbol Search & .699 & $.041(.053)$ \\
\multicolumn{2}{c}{$r$ [load on $g$ and $r$ (mother - offspring) $]=.842(.778)^{*}$}
\end{tabular}

Note. Information, Similarities, Block, Symbol Search, and Code are subtests of the WISC-III. Toulouse is an attention test, and the SPM $=$ Standard Progressive Matrices of Raven. Between parentheses are values of correlations corrected for attenuation. $* p<.05$.

In addition, genetic $\mathrm{x}$ environmental interaction was estimated. The difference between the mother's IQ subtest score and that of her child was estimated (Table 3), and then the differences were adjusted for SES. Using a linear model, the results indicated a tendency for children to have a higher IQ than their mothers in low-SES families, when compared to middle-high SES families. However this result was only marginally significant $(p=.084)$ for mothers that had attained university level education (Figure 1).

Table 3

Performance of mothers and offspring according to SES on the $S P M$ test using an IQ scale

\begin{tabular}{lccccc}
\hline \multirow{2}{*}{ Family SES } & \multicolumn{2}{c}{ Mothers } & \multicolumn{2}{c}{ Offspring } & Difference \\
\cline { 2 - 5 } & $M$ & $S D$ & $M$ & $S D$ & \\
\hline Low $(n=64.4 \%)$ & 98.6 & 12.3 & 100.1 & 9.3 & -1.53 \\
$\begin{array}{l}\text { Middle-High } \\
(n=35.6 \%)\end{array}$ & 102.7 & 11.9 & 99.6 & 9.4 & 3.05 \\
Total & 100.0 & 12.3 & 99.9 & 9.1 & - \\
\hline
\end{tabular}

The Pearson correlation between $g$ load and the relationship between cognitive performance of mothers and their offspring $(r=.842$, or .778 , when corrected for attenuation) was statistically significant $(p=.02)$, and approaching significance when Spearman correlation was considered $(r h o=.750, p=.052$; same value when corrected for attenuation). Thus, the correlation between the cognitive performance of mothers and offspring decrease (or increase) when decrease (or increase) the $g$ load of cognitive measures. Additionally, only crystallized measures, such as information $(r=.192 ; p=.005)$ and similarities $(r=.201 ; p=.005)$ were significantly associated with cognitive performance of mothers. For fluid measures (SPM or Block Design) or attention measures (Code and Toulouse), no significant

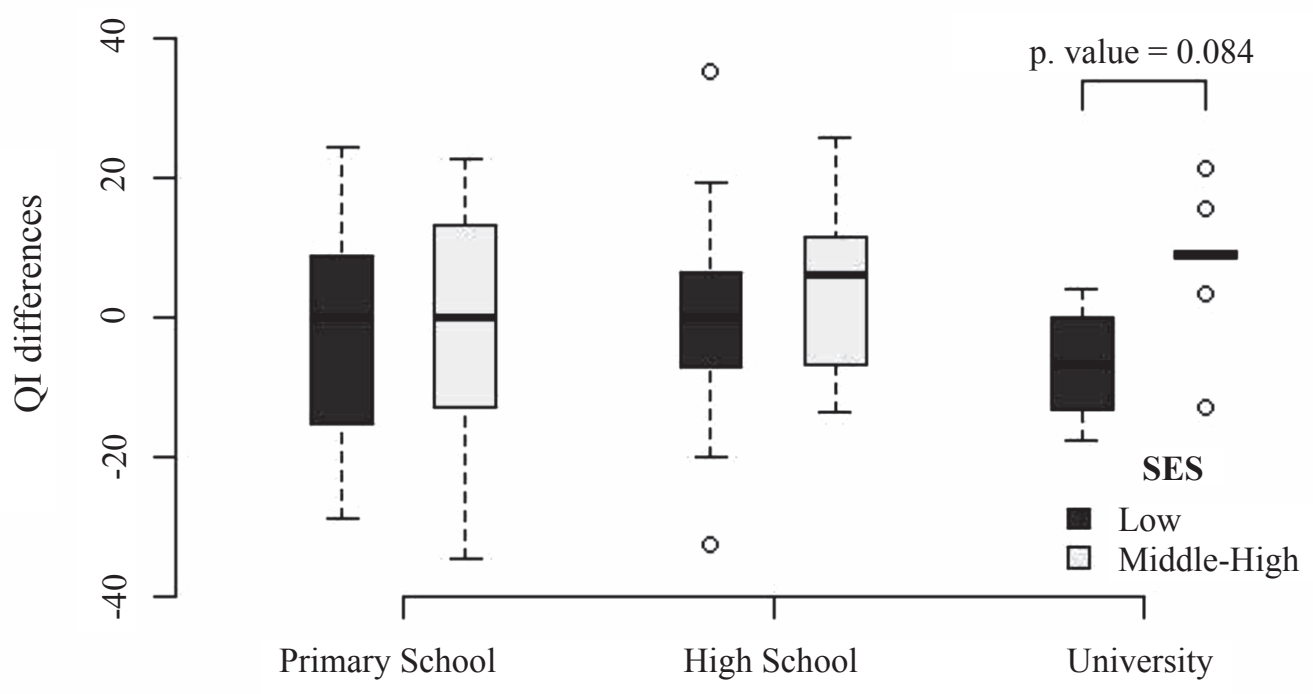

Figure 1. Mean differences in IQ points (using standardized scores from the SPM test), between mothers and their offspring, according to education of mother from low and middle-high SES (negative differences favoring offspring; positive differences favoring mothers). 
correlation between cognitive performance of mothers and their children were found.

\section{Discussion}

Three interesting points emerged from the results of the present study. First, as Jensen had previously indicated (Jensen, 1998), the column vector of $g$ (composed of the $g$ loadings from a set of cognitive measures) had a significant correlation with the heritability vector from a set of cognitive measures (mother-offspring correlation on each test). This results means that cognitive similarity between mothersoffspring may depend on $g$ loadings of tests employed in the assessment.

Second, despite the fact that all correlations between cognitive performance of mothers and their offspring were positive, all values were very low (the highest correlation was .177 or .201 , corrected for attenuation). This result contradicts previously published studies demonstrating parent-offspring resemblance on intelligence tests (Bouchard \& McGue, 1981; Erlenmeyer-Kimling \& Jarvik, 1963; Reed \& Rich, 1982; van Leeuwen, van den Berg, \& Boomsma, 2008). In these studies, moderate correlations (approximately .50) were measured. In this regard, it must be noted that Caruso (1983) had observed a heterogeneity of parent-offspring IQ correlations. The correlations for the samples included in his meta-analysis ranged from .15 to .80 . According to Caruso, sampling error, attenuation due to unreliability, and attenuation due to restriction of range, usually account for variability in the correlations. In the present study, sampling error could account for the low correlations in so far as our sample, apart small size, was mostly composed by children ( $70 \%$ until 12 years old), few adolescents (30\%) and no adult offspring. Age is an important variable in studies investigating familial cognitive resemblance since heritability appears to increase with age, i.e., the influence of shared environment is stronger during childhood and disappears during adolescence when genetic factors begin to play a more important role (Scarr \& Weinberg, 1983; van Leeuwen et al., 2008). However, after dividing our sample into two age groups ( $\leq 12$ years old, and $\geq 13$ years old), no evidence of increased correlation was observed in the older group.

Another possible interpretation for explaining the results obtained is related to the impact of the SES variable. Our results were similar to those obtained by Turkheimer et al. (2003), where heritability was estimated at .10 in twins from low-SES mothers. Our study refers to individuals that are less biological related than twins. It refers to mothers and their children, where approximately $67 \%$ were categorized as low-SES families (the remainder, 33\%, was middle-high class. No participating families were from high or extreme low SES). Thus, it is possible to infer that cognitive ability heritability is sensitive to environmental conditions.

Third, the kinship correlation was statistically significant, only for crystallized measures (Information and Similarities), but not fluid measures (SPM or Block Design) or attention measures (Code, Toulouse Test, and
Symbol Search). This result seems to be counter intuitive considering the mainstream psychometric intelligence literature, which indicates that fluid intelligence (the closest psychological construct to $g$ ) is supposedly culture-free (or, at least, less influenced by cultural factors). Thus, $h^{2}$ of fluid intelligence should be higher than crystallized intelligence. However, our results are consistent with Kan et al. (2013) who observed the same surprising result after analyzing 23 twin studies $(N=7,852)$. These authors found that the heritability coefficients of culture-loaded tests (crystallized measures) tended to be larger than those of culture-reduced tests (fluid measures). Kan et al., considered their own results to be difficult to interpret, without appreciating the role of education, culture and experience, in the development of heritable intelligence. According to these authors, societal demands could determine the load $g$ of tests and, pressing the inclusion of the effects of genotype-environment covariance on heritability coefficients.

Moreover, a meta-analysis recently conducted by Pietschnig and Voracek (2015) of trajectories of the Flynn effect across cognitive abilities, from 1909 to 2013, indicated strongest gains for $G f$ than $G c$, which in some way could be linked to the study of Kan et al. (2013), and to our present study. These last two studies found more heritability for $G c$ than $G f$, which implies that cognitive gains through generations can be better expressed in changes in $G f$ than in $G c$. Assuming that $G c$ is more heritable, it is possible to expect a larger correlation between mothers and offspring if both were assessed with crystallized measures, which did not happen in our study. According to Pietschnig and Voracek, the reason why $G f$ would be less heritable than $G c$ is that $G f$, over time, could be being incremented by exposition of students to tests with multiple-choice response, improved nutrition and reduced pathogen stress. These factors could be differentiated among participants (mothers and offspring) of our study.

If the hypothesis of influence of genotype-environment covariance (through abilities Gf/Gc and SES) on heritability coefficients of the intelligence is true or not, the results obtained in the present study seem to validate it.

Finally, the differences in cognitive performance (controlling for age) between mothers and offspring from the same cognitive measure (the SPM test) were estimated. The results (Figure 1) indicated improved cognitive performance in offspring when compared to their mothers from low-SES families, when compared to children from middle-high-SES families, especially children from mothers with university level education. To verify the interaction between education and mother's SES in reference to "IQ differences" (IQ was entered as a categorical variable - positive or negative), a logistic model (Agresti, 2002) was implemented. The following was observed: $89 \%$ of mothers with university education from middle-high-SES versus $25 \%$ from low-SES had an IQ score higher than their offspring. This proportional difference was significant $(p=.045)$. Hence, the results seem to indicate that rising intelligence test performance across generations in families (Flynn effect) presents a greater probability in low-SES families. These results are similar 
to those found in cognitive comparison studies between countries, where Flynn effects are observed in developing nations, while they are diminishing in developed countries (Meisenberg \& Woodley, 2013).

The present study was a kinship study, in which Brazilian mothers and their offspring $(N=141)$ were administered the SPM test. Additionally, six other cognitive measures were administered, only to the offspring. The results indicated evidence of heritability of $g$ (the greater the loaded $g$ test, the greater the association between cognitive performance of mother and their offspring), which is supported by others in the literature. Nevertheless, heritability coefficients of each test were low, and significance was only observed for crystallized (Information and Similarities) instead fluid measures (SPM, Block Design, Code), which is apparently contrary to the literature. On the other hand, IQ differences between mothers-offspring in the same measure (SPM test) tended to be negative in low-SES families (offspring had higher performance than mothers) and positive in middlehigh-SES families (offspring had less performance than mothers). The authors of this study are inclined to consider the hypothesis of Kan et al. (2013) and the studies of Harden et al. (2007), Tucker-Drob and Bates (2016) and Turkheimer et al. (2003) to explain the obtained results. The genotypeenvironment covariance through SES could influence the coefficients of cognitive heritability, where $G c$ would be more inheritable than $G f$. However, we recognize that the size of sample employed (relatively small), the absence of high and extreme low social class families, and the administration of just one cognitive measure to mothers (the SPM test) do not permit to robust conclusions, and they are recognized as limitation of the present study. It is not easy to design a study in which parents and their children are tested simultaneously. For this reason, recruiting representative samples remains a challenge for researchers. Despite these limitations, this study does provide new information regarding intelligence in respect to nature versus nurture.

\section{References}

Agresti, A. (2002). Categorical data analysis. New York, NY: John Wiley \& Sons.

Araujo, R. S. (2011). Teste de atenção concentrada Toulouse-Pierón: Atualização dos estudos de padronização, validade e precisão [ToulousePieron Concentrated Attention Test: Updating of standardization, validity and reliability studies]. Unpublished master's dissertation. Universidade de Sao Paulo, Sao Paulo, Sp. Retrieved from http://www. teses.usp.br/teses/disponiveis/47/47131/publico

Associação Brasileira de Empresas de Pesquisa. (2008). Critério de classificação econômica Brasil [Brazil economic classification criterion]. Retrieved from http://www.abep.org/criterioBrasil.aspx

Bouchard, T. J., Jr., \& McGue, M. (1981). Familial studies of intelligence: A review. Science, 212(4498), 10551059. doi:10.1126/science. 7195071
Brouwer, R. M., van Soelen, I. L. C., Swagerman, S. C., Schnack, H. G., Ehli, E. A., Kahn, R. S., ... Boomsma, D. I. (2014). Genetic associations between intelligence and cortical thickness emerge at the start of puberty. Human Brain Mapping, 35(8), 3760-3773. doi:10.1002/hbm.22435

Caruso, D. R. (1983). Sample differences in genetics and intelligence data: Sibling and parent-offspring studies. Behavior Genetics, 13(5), 453-458. doi:10.1007/ BF01065921

Colom, R., Juan-Espinosa, M., \& Garcia, L. F. (2001). The secular increase in test scores is a "Jensen effect". Personality and Individual Differences, 30(4), 553559. doi:10.1016/S0191-8869(00)00054-4

Deary, I. J. (2012). Intelligence. Annual Review of Psychology, 63, 453-482. doi:10.1146/annurevpsych-120710-100353

Deary, I. J., Johnson, W., \& Houlihan, L. M. (2009). Genetic foundations of human intelligence. Human Genetics, 126(1), 215-232. doi:10.1007/s00439-0090655-4

Dickens, W. T., \& Flynn, J. R. (2001). Heritability estimates versus large environmental effects: The IQ paradox resolved. Psychological Review, 108(2), 346369. doi:10.1037//0033295X.108.2.346

Erlenmeyer-Kimling, L., \& Jarvik, L. F. (1963). Genetics and intelligence: A review. Science, 142(3598), 14771478. doi:10.1126/science.142.3598.1477

Flores-Mendoza, C., Widaman, K., Mansur-Alves, M., Dias Bacelar, T., \& Saldanha, R. (2013). Psychoticism and disruptive behavior can be also good predictors of school achievement. Spanish Journal of Psychology, 16, E13. doi:10.1017/sjp.2013.3

Flynn, J. R. (1994). IQ gains over time. In R. J. Sternberg (Ed.), Encyclopedia of human intelligence (pp. 617623). New York, NY: MacMillan.

Flynn, J. R. (1999). Searching for justice: The discovery of IQ gains over time. American Psychologist, 54(1), 5-20. doi:10.1037//0003-066X.54.1.5

Gottfredson, L. S. (1997). Why g matters: The complexity of everyday life. Intelligence, 24(1), 79-132. doi:10.1016/S0160-2896(97)90014-3

Hanscombe, K. B., Trzaskowski, M., Haworth, C. M. A., Davis, O. S. P., Dale, P. S., \& Plomin, R. (2012). Socioeconomic status (SES) and children's intelligence (IQ): In a large UK-representative sample SES moderates the environmental, not genetic, effect on IQ. PloS One, 7(2), e30320. doi:10.1371/journal.pone.0030320

Halsey, A. H. (1958). Genetics, social structure and intelligence. The British Journal of Sociology, 9(1), 15-28. doi:10.2307/587619

Harden, K. P., Turkheimer, E., \& Loehlin, J. C. (2007). Genotype by environment interaction in adolescents' cognitive aptitude. Behavior Genetics, 37(2), 273-283. doi:10.1007/s10519-006-9113-4 
Horn, J. L. (1994). Theory of fluid and crystallized intelligence. In R. J. Sternberg (Ed.), Encyclopedia of human intelligence (pp. 443-451). New York, NY: MacMillan.

Hunt, E. (2010). Human intelligence. New York, NY: Cambridge University Press.

Jensen, A. R. (1998). The $g$ factor: The science of mental ability. Westport, CT: Praeger.

Johnson, W., \& Bouchard, T. J., Jr. (2007). Sex differences in mental abilities: $G$ masks the dimension on which they lie. Intelligence, 35(1), 23-39. doi:10.1016/j. intell.2006.03.012

Kan, K.-J., Wicherts, J. M., Dolan, C. V., \& van der Maas, H. L. J. (2013). On the nature and nurture of intelligence and specific cognitive abilities: The more heritable, the more culture dependent. Psychological Science, 24(12), 2420-2428. doi:10.1177/0956797613493292

Luo, D., Petrill, S. A., \& Thompson, L. A. (1994). An exploration of genetic $\mathrm{g}$ : Hierarchical factor analysis of cognitive data from the Western Reserve Twin Project. Intelligence, 18(3), 335-347. doi:10.1016/01602896(94)90033-7

Lynn, R., \& Hattori, K. (1990). The heritability of intelligence in Japan. Behavior Genetics, 20(4), 545546. doi:10.1007/BF01067719

McAskie, M., \& Clarke, A. M. (1976). Parents-offspring resemblances in intelligence: Theories and evidence. British Journal of Psychology, 67(2), 243-273. doi:10.1111/j.2044-8295.1976.tb01514.x

McCall, R. B. (1970). Intelligence quotient pattern over age: Comparisons among siblings and parent-child pairs. Science, 170(3958), 644-648. doi:10.1126/ science. 170.3958 .644

McGrew, K. S., Flanagan, D. P., Keith, T. Z., \& Vanderwood, M. (1997). Beyond g: The impact of GfGc specific cognitive abilities research on the future use and interpretation of intelligence tests in the schools. School Psychology Review, 26(2), 189-210.

Meisenberg, G., \& Woodley, M. A. (2013). Are cognitive differences between countries diminishing? Evidence from TIMSS and PISA. Intelligence, 41(6), 808-816. doi:10.1016/j.intell.2013.03.009

Montgomery, D. C., Peck, E. A., \& Vining, G. G. (2006). Introduction to linear regression analysis. Hoboken, NJ: Wiley-Interscience.

Nagoshi, C. T., \& Johnson, R. C. (2005). Socioeconomic status does not moderate the familiality of cognitive abilities in the Hawaii family study of cognition. Journal of Biosocial Science, 37(6), 773-781. doi:10.1017/S0021932004007023

Nisbett, R. E., Aronson, J., Blair, C., Dickens, W., Flynn, J., Halpern, D. F., \& Turkheimer, E. (2012). Intelligence: New findings and theoretical developments. American Psychologist, 67(2), 130-159. doi:10.1037/a0026699
Pietschnig, J., \& Voracek, M. (2015). One century of global IQ gains: A formal meta-analysis of the Flynn effect (1909-2013). Perspectives on Psychological Science, 10(3), 282-306. doi:10.1177/1745691615577701

Plomin, R., \& DeFries, J. C. (1980). Genetics and intelligence: Recent data. Intelligence, 4(1), 15-24. doi:10.1016/0160-2896(80)90003-3

Rainho, O. (2001). Bateria fatorial CEPA: Testes de Aptidões Específicas. Manual [CEPA Factorial Battery: Specific Abilities Tests] (2a ed.). Rio de Janeiro, RJ: CEPA.

Raven, J. C. (2001). Standard progressive matrices: Sets $A-E$, manual. Rio de Janeiro, RJ: CEPA.

Reed, S.C., \& Rich, S.S. (1982). Parent-offspring resemblances and regressions for IQ. Behavior Genetics, 12, 535-542.

Rowe, D. C., \& Rodgers, J. L. (2002). Expanding variance and the case of historical changes in IQ means: A critique of Dickens and Flynn (2001). Psychological Review, 109(4), 759- 763. doi:10.1037/0033-295X.109.4.759

Rowe, D.C., Jacobson, K.C., \& Van den Oord, E.J.C.G. (1999). Genetic and Environmental Influences on Vocabulary IQ: Parental Education Level as Moderator. Child development, 70, 1151-1162.

Scarr, S., \& Weinberg, R. A. (1983). The Minnesota Adoption Studies: Genetic differences and malleability. Child Development, 54(2), 260-267. doi:10.2307/1129689

Scarr-Salapatek, S. (1971). Race, social class, and IQ. Science, 174(4016), 1285-1295. doi:10.1126/ science.174.4016.1285

Tucker-Drob, E.M., \& Bates, T.C. (2016). Large CrossNational Differences in Gene x Socioeconomic Status Interaction on Intelligence. Psychological Science, 27, 138-149.

Turkheimer, E., Haley, A., Waldron, M., D’Onofrio, B., \& Gottesman, I. I. (2003). Socioeconomic status modifies heritability of IQ in young children. Psychological Science 14(6), 623-628. doi:10.1046/j.0956-7976.2003. psci_1475.x

van Leeuwen, M., van den Berg, S. M., \& Boomsma, D. I. (2008). A twin-family study of general IQ. Learning and Individual Differences, 18(1), 76-88. doi:10.1016/j. lindif.2007.04.006

Venables, W. N., Smith, D. M., \& R Core Team. (2015). An introduction to $R$. Notes on $R$ : A programming environment for data analysis and graphics: Version 3.2.2. Retrieved from https://cran.r-project.org/doc/ manuals/R-intro.pdf

Wechsler, D. (2002). WISC III: Escala de inteligência Wechsler para crianças [WISC III: Wechsler Intelligence Scale for Children: Manual] (V. L. M. Figueiredo, Trans.). São Paulo, SP: Casa do Psicólogo. 
Woodley, M. A., Fernandes, H. B. F., \& Hopkins, W. D. (2015). The more g-loaded, the more heritable, evolvable, and phenotypically variable: Homology with humans in chimpanzee cognitive abilities. Intelligence, 50, 159-163. doi:10.1016/j.intell.2015.04.002

Carmen Flores-Mendoza is an Associated Professor of the Faculty of Human Sciences, Department of Psychology and Neuroscience Program at Universidade Federal de Minas Gerais.

Bruna Miranda Carvalhais Santiago is a Master candidate of the Neuroscience Programa at Universidade Federal de Minas Gerais.

Daniel Marcos Andrade is a Ph.D. candidate of the Graduate Program in Psychology at Universidade Federal de Minas Gerais

Walkiria Peliky Fontes is a psychologist, Master's degree in Human Development Psychology.

Larissa Assunção Rodrigues is a Professor of the Faculty of Human Sciences, Department of Psychology at Universidade Federal de Minas Gerais

César Augusto Mansur Tuma is a Master candidate of the Neuroscience Programa at Universidade Federal de Minas Gerais.

Received: Nov. 9, 2015

1st Revision: Mar. 25, 2016

Approved: Apr. 12, 2016

How to cite this article:

Flores-Mendoza, C. E., Santiago, B. M. C., Andrade, D. M., Fontes, W. P., Rodrigues, L. A., \& Tuma, C. A. M. (2017). Mothers-Offspring resemblance in intelligence and its relationship to Socioeconomic Status. Paidéia (Ribeirão Preto), 27(66), 98-106. doi: 10.1590/198243272766201712 